\section{NEW RECORD OF FRUIT GALL ON STEREOSPERMUM CHELENOIDES (L.F.) DC. CAUSED BY A MITE (ERIOPHYIDAE: ACARINA)}

\section{D.K. Kulkarni ${ }^{1}$, A.S. Upadhye ${ }^{1}$, M.R. Shindikar ${ }^{1}$ and R.M. Sharma ${ }^{2}$}

${ }^{1}$ Agharkar Research Institute, Gopal Ganesh Agarkar Road, Pune, Maharashtra 411004, India

${ }^{2}$ Zoological Survey of India, High Altitude Zoology Field Station, Saproon, Solan, Himachal Pradesh 173211, India

Galls or plant tumors are structural deformities arising mostly by overgrowth (hypertrophy) and excessive cell division of tissues (hyperplasy). Gall formation is a product of interspecific association between a plant and other pathogenic organism or physiological changes in the plant body itself. The galls induced by vegetative parasites are called 'phytocecidia' while animal parasites are termed 'cecidozoa' (Mani, 2000). There are a number of gall causing organisms found to induce gall in various parts and stages of plant (Mani, 1964). Some of these galls are reported for their medicinal values particularly in Ayurvedic preparations (Upadhye et al., 1993) and traditional agricultural practices (Singhvi \& Sharma, 1985).

The fruit galls are found to be initiated by cecidogenetic reaction on the plant in the immature fruit stage, after the pollination of the flower and fertilization of the ovary. In this connection, some outstanding observations on fruit galls have been studied in the world. Some examples are reported in India like unilocular midge gall on the fruits of Zizyphus xylopyra Willd and irregularly globose, rugose, multilocular solid gall on fruits of Acacia concinna DC. Fruits of Acacia leucopholea Willd show galls formed by the fungus Uromycladium. Narasimhan (1954) reported malformation of panicle in Mango by Eriophyes mite. Oval, solid, fibrous agglomerate, multilocular blisters arise on half mature fruits of Terminalia paniculata Roth. caused by a psyllid, Trioza hirsute (Crawf.). Fruits of Terminalia arjuna W\&A show subglobose, truncated swellings caused by an unknown cynipid (Hymenoptera), whereas normal development of fruit in Ludwigia adscendens (L.) has been observed to be arrested by an unknown weevil. Globose, fleshy, unilocular swellings with a short nipple-like and blunt apical process arise on fruits of Maesa indica (Roxb.) caused by an unknown midge. However, during the literature survey it was noticed that gall formation on fruits of genus Stereospermum has not been reported so far.

Genus Stereospermum belongs to family Bignoniaceae and plays an important part in the floristic composition as well as in ayurvedic medicines. Two species, Stereospermum chelenoides (L.f.) DC. (=S. suaveolens (Roxb.) DC.) and Stereospermum colais (Buch.-Ham. ex Dillw.) Mabb. $(=S$. chelenoides auct. non (L.f.) DC.) are mainly used since ancient times. Very little attention has been paid to study their distribution, germination and germplasm collection. During regular botanical excursions in Maharashtra, the authors collected the germplasm of above species from different localities, such as from remote forested hilly areas of Alapali forest in Gadchiroli district in December 1994 and collected 810 fruits of Stereospermum chelenoides (L.f.) DC. The fruits of Stereospermum were of capsule type $(30-50 \mathrm{~cm}$ by $2-3 \mathrm{~cm})$. These pods were straight, cylindrical, slightly ribbed somewhat rough with elevated whitish spikes and thick valve. Out of these, three pods had developed galls, which were not previously reported. The infection caused structural deformity due to dark brownish-grey coloured dumbbell shaped overgrowth (1$1.5 \mathrm{~cm}$ diameter) (Figure 1$)$. We found about 8-10 irregular galls on each pod.
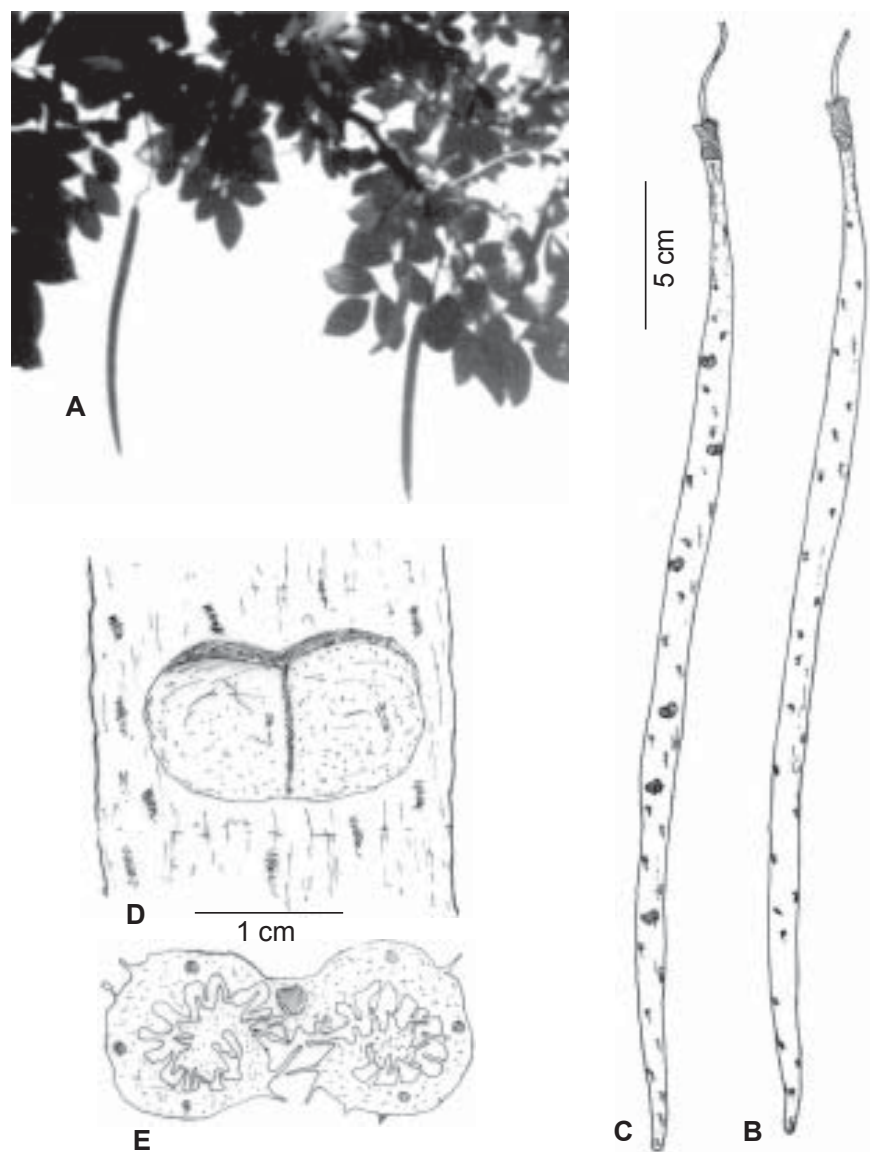

Figure 1. A - Fruiting of Steriospermum chellenoides;

B - An uninfected pod; C - Infected pod showing galls; $D$ - Close up of a dumbbell shaped gall; $E$ - A section of gall showing bi-locular anatomy

The present gall formation in fruits of Stereospermum chelenoides was due to Eriophyes mites belonging to family Eriophyidae. This is an important group of Cecidozoa having minute, elongated, cylindrical mites. Enough specimens could not be retrieved from the gall, hence the identification is given up to generic level only. An attempt was made to study detailed microscopic characters of these galls. Due to infection of this mite, extensive proliferation in some parts of the fruits resulting in adverse effects on the rate of cell division, degree of differentiation, intake of nutritive substances, respiration, concentration of enzymes and hormones, etc. were affected. It 
restraining it. To rule out any nutritional cause, the feed ingredients were checked and found to be normal. The

also affected seed development in fruits. The larvae of the cecidozoa may be situated in the septa or in the cavity of the fruits. Horizontal section of gall showed Eriophyes spreading from the pierced cell. The effect of the reaction of the cell spread to other cells immediately in contact and only to a lesser extent to the cells away from the area of infection. The nuclear gigantism of the cell was attacked by the Eriophyes mites. This gall is used by tribals for medicinal purposes and thus constitutes an important record in the database of plant galls.

\section{REFERENCE}

Mani, M.S. (1964). Ecology of plant galls. Dr. W. Junk, Publishers, The Hague, Netherlands.

Mani, M.S. (2000). Plant Galls of India ( $2^{\text {nd }}$ Edition) Oxford \& IBH Publishing Co. Pvt. Ltd., New Delhi, 354pp.

Narasimhan, M.J. (1954). Malformation of panicles in Mango incited by a species of Eriophyes. Current Science 23: 297-298.

Singhvi, N.R. and K.D. Sharma (1985). A report on effect of aqueous extract of the galls of Ficus racemosa L. on seed germination and seedling growth of pearl millet (Pennisetum typhoideum Rich.). Geo Bios 12: 153-154.

Upadhye, A.S., V.D.Vartak and M.S. Kumbhojkar (1993). On the identity of market samples of the drug 'Kakadshingi'. Bulletin of MedicoEthno Botanical Research 15(1-2): 85-88.

\section{ACKNOWLEDGements}

We thank Dr. V.S. Rao, Director, Agharkar Research Institute, Pune for providing the necessary facilities. Discussion with Dr. V.G. Rao, Department of Mycology and Plant Pathology is gratefully acknowledged. Thanks are also due to the Director, Zoological Survey of India, Kolkata for encouragement.

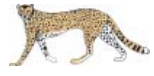

VET BRIEF ZOOS' PRINT JOURNAL 20(5): 1876

\section{ACARIASIS IN AN EMU (DROMAIUS NOVAELLANDIAE) - A CASE REPORT}

\section{K. Senthil Kumar ${ }^{1}$, R. Thirumurugan ${ }^{2}$, K. Devaki ${ }^{1}$ and Pathan Nazrullah Khan ${ }^{3}$}

${ }^{1}$ Veterinary Assistant Surgeons, ${ }^{2}$ Zoo Veterinarian, ${ }^{3}$ Veterinary Officer, Arignar Anna Zoological Park, Vandalur, Chennai, Tamil Nadu 600048, India

Birds serve as hosts for a wide variety of ectoparasites including ticks and mites (Greve, 1986). These not only cause annoyance to the birds but also spread many pathogens including blood protozoa. The infestation by ectoparasites may alter the birds' behavior by reducing their appetite and result in constant preening and pecking of the affected parts. The present report puts on record, a case of tick infestation and its treatment in a captive emu.

The prestigious ratite a female Emu (Dromaius novaellandiae) in the Arignar Anna Zoological Park, Vandalur, was reported of having inappetance, constant preening and pecking and altered gait. The bird was active and responded to the keeper's call. A thorough clinical examination was carried out by physically droppings were examined and no ova or eggs of helminths were detected.

The bird preened the feathers particularly over the back region, which was examined thoroughly for wound, growths, inflammation or ectoparasites; no abnormalities could be detected. Then the whole body was examined, which revealed numerous ticks over the skin around the ear canal and lateral sides of the neck resulting in the observed symptoms. The ticks were collected for identification and were identified as Heamaphysalis sp. (Soulsby, 1986).

Treatment: The condition was treated by applying Deltamethrin solution (BUTOX liquid - Hoechst India Ltd.,) @ 2ml per liter of water sprayed on the affected areas taking care to avoid contact with eyes, left for twenty minutes and cleaned with water. The bird showed improvement from the next day and complete recovery in three days. The enclosure was also sprayed with the acaricide in higher concentration, after shifting the bird to a nearby enclosure. The treatment was repeated after a week to prevent reinfestation.

In this case it was difficult to identify the ticks because of the colour of the feathers and skin. The infestated area seemed almost normal, with the ticks visible only on close and careful observation. The ticks were found localized in the head and neck regions. Greve (1986) opined that avain hard ticks prefer the head region where they are protected from being dislodged by preening. In this case, the bird was found preening the feathers over the back, but it was actually attempting to remove the ticks by rubbing the head and neck, which resulted in the altered gait.

Greve (1986) stated that wild birds might be responsible for the introduction of ticks into bird exhibits. The zoological park contains numerous free ranging peafowls and, the emu enclosure being an open enclosure, they frequent the enclosure in search of feed. Subramanian et al. (2002) reported the occurrence of ticks belonging to Heamaphysalis sp. in free ranging peafowls. So the peafowls might be the source of introduction.

The acaricide used in this case was found to be very effective in controlling the ticks. Greve (1986) suggested the use of rotenone, pyrethrin-piperonyl butoxide, malathion and carbaryl as safe and effective acaricides to be used on the birds.

To prevent such occurrences in future, it was planned to conduct periodic clinical examination of the bird and the enclosure and to take measures to avoid contact with free ranging peafowls.

\section{REFERENCES}

Greve, J.H. (1986). Parasitic diseases. In: Fowler, M.E. Zoo and wild Animal medicine. $2^{\text {nd }}$ edition. W.B. Saunders Company, Philadelphia, 234 p.

Soulsby, E.J.I. (1982). In: Helmints, Arthropods and Protozoa of Domestic Animals. $7^{\text {th }}$ edition. ELBS, London.

Subramanian, K.S. and M. Raman (2002). Indian Veterinary Journal 79: 276.

\section{ACKNOWLedgement}

The authors are thankful to the Director, Arignar Anna Zoological Park, Vandalur, Chennai for permitting to undertake the work.

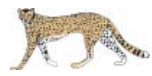

(C) Zoo Outreach Organisation; www.zoosprint.org Manuscript 1097; Received 09 October 2003; Finally accepted 17 December 2004; Date of publication 21 April 2005 